\title{
PERLOKUSI HOAKS COVID-19: PERSPEKTIF CYBERPRAGMATICS
}

\author{
R. Kunjana Rahardi \\ Universitas Sanata Dharma Yogyakarta \\ email: kunjana.rahardi@gmail.com
}

\begin{abstract}
Abstrak
Hoaks adalah berita palsu yang menggunakan bahasa sebagai medianya, tetapi bukan bahasa dalam fungsi sesungguhnya. Penelitian ini bertujuan mendeskripsikan perlokusi hoaks Covid-19 di media sosial. Perspektif yang digunakan adalah Cyberpragmatics. Pendekatan yang diterapkan adalah deskriptif kualitatif. Objek sasaran penelitian ini adalah manifestasi perlokusi hoaks Covid-19. Data penelitian berupa cuplikan-cuplikan tuturan yang di dalamnya terdapat manifestasi-manifestasi perlokusi hoaks Covid-19. Sumber data substantif penelitian ini teks-teks tertulis yang terdapat di media sosial. Adapun sumber data lokasionalnya adalah media-media sosial seperti Instagram, Facebook, Blog, Webs, yang hadir di sekitar waktu penelitian. Data dikumpulkan dengan metode simak. Teknik yang digunakan adalah teknik rekam dan teknik catat. Sebelum dilakukan analisis data, validitas data dipastikan terlebih dahulu dengan triangulasi data. Metode analisis yang diterapkan adalah metode analisis ekstralingual. Adapun teknik yang diterapkan adalah teknik hubung banding khususnya teknik hubung banding menyamakan. Penelitian ini menghasilkan temuan perlokusi hoaks Covid-19 berikut ini: (1) mengentalkan rasa sentimen; (2) menumbuhkan perspepsi keliru; (3) menyindir otoritas; (4) menumbuhkan kegaduhan; (5) menebar ketakutan; (7) menumbuhkan kekhawatiran; dan (8) menumbuhkan kasak-kusuk.
\end{abstract}

Kata Kunci: Cyberpragmatics, konteks eksternal virtual, dampak perlokusi

\section{THE HOAKS PERLOCUSION COVID-19: CYBERPRAGMATICS PERSPECTIVE}

\begin{abstract}
Hoax is fake news that uses language as the medium, but not language in its true function. The main objective of this study is to describe the perlocutionary impact of Covid-19 hoaxes. The research perspective used was cyberpragmatics. The approach applied was descriptive qualitative. The object of this research was the manifestation of Covid-19 perlocutionary hoaxes. The research data were snippets of speech in which there were manifestations of Covid-19 hoaxes. The substantive data source of this research was written texts contained in the social media. The locational data sources were social media such as Instagram, Facebook, Blogs, Webs, which were present around the time of research. Data were collected by applying the listening method. The technique used was the recording technique and note taking technique. Before data analysis was performed, the validity of the data was confirmed in advance by applying data triangulation. The data analysis method applied was the extra-lingual
\end{abstract}


analysis method or the extra-lingual equivalent analysis method. The technique applied was the appeal link technique, especially the equalization link technique. This study produced the following findings of the impacts of Covid-19 perlocutionary hoaxes, namely (1) making thickened sentiment; (2) fostering wrong perceptions; (3) insinuating authority; (4) creating noise; (5) spreading fear; (6) fostering concern; (7) growing gossips.

Keywords: Cyberpragmatics, virtual external context, perlocutionary impacts

\section{PENDAHULUAN}

Dalam perspektif linguistik semakin bertambahnya jumlah hoaks menunjukkan bahwa sesungguhnya bahasa tidak lagi diperantikan sebagaimana mestinya oleh penuturnya (Chen, 2017). Hoaks hakikatnya adalah berita bohong atau berita palsu. Berita demikian itu juga memerantikan bahasa sebagai medianya, tetapi bukan bahasa dalam fungsi sesungguhnya. Sebab fungsi hakiki bahasa adalah sebagai sarana pengembang akalbudi (Sudaryanto, 2015). Kalau bahasa diperantikan untuk berbohong dan menyebarkan berita palsu, sesungguhnya tidak ada sejengkal pun akal budi yang dikembangkan dengan wahana itu. Jika yang terlahir dari pemerantian bahasa adalah keberingasan-keberingasan sosial, tidak ada sedikit pun nuansa pengembangan akal budi yang terdapat di dalamnya.

Fungsi hakiki dalam tataran lebih rendah dari yang disebutkan pertama adalah fungsi pengukuh kerja sama. Bahasa hadir untuk mengemban fungsi kemasyarakatan, yakni menjadikan hubungan antarsesama, baik secara horizontal maupun vertikal (2017b), (Pranowo, 2020). Jika yangterjadidalam pembuatan dan penyebaran hoaks itu adalah kekacauan dan keributan antarsesama, harus ditegaskan bahwa fungsi membangun kerja sama itu sama sekali tidak terlaksana. Jika masyarakat direndahkan kesadaran kritisnya, sehingga mereka mudah digiring ke dalam kepentingan-kepentingan tertentu dengan memerantikan berita bohong tertentu yang diembuskan, harus dikatakan bahwa kerja sama antarsesama dengan peranti bahasa itu sama sekali tidak terlaksana.

Penulis hendak menegaskan bahwa penyebaran berita palsu terkait dengan Covid-19, sesungguhnya adalah realitas pengawafungsian bahasa. Bahasa telah diawafungsikan, telah difungsikan secara keliru, sehingga yang terjadi adalah kekacauan dan kegaduhan di dalam masyarakat. Adalah sebuah ironi bahwa di tengah keprihatinan mendalam terkait merebak cepatnya pandemi Covid-19, penyebaran hoaks Covid-19masih terus saja terjadi. Dalam kaitan dengan hal ini, media sosial perlu merumuskan posisinya kembali sebagai wahana yang berfungsi menjembatani dan memfasilitasi hubungan sosial antarwarga masyarakat.

Beberapa penelitian terdahulu yang relevan terkait dengan perspektif cyber dan penelitian yang terkait dengan tindak tutur ilokusi telah dilakukan. Dengan data dari sejumlah cerpen, Kusmarwanti (2010) memerikan aspekaspek karya sastra dengan data dari 
cerpen-cerpen yang dimuat dalam website. Penelitian ini setidaknya dapat dipandang relevan dengan tulisan ini karenakeduanyaberbicaratentangperan dari dimensi-dimensi siber. Tulisan ini berbeda dengan yang dilakukan oleh Kusmarwanti (2010) karena perspektif yang diterapkan adalah cyberpragmatics dengan sumber data dari media sosial. Selanjutnya, penelitian terkait tindak tutur ilokusi juga pernah dilakukan oleh Handayani dkk., (Handayani, 2016). Akan tetapi sumber data penelitian tersebut bukan dari media sosial melainkan dari sebuah buku. Dengan demikian substansi tulisan ini dapat dianggap gayut dengan penelitian tersebut dalam arti bahwa keduanya berbicara tentang tindak tutur, sekalipun yang satu berbicara ihwal ilokusi dan yang satunya berbicara ihwal perlokusi. Sumber data dari kedua penelitian tersebut juga berbeda, karena yang satu bersumber pada buku dan yang satunya bersumber pada media sosial.

Selanjutnya, teori yang mendasari penelitian ini pertama-tama adalah teori pragmatik siber (Yus, 2011), (Cyber, 2004), (Indrayani \& Johansari, 2019). Pragmatik dibedakan menjadi bermacam-macam, di antaranya adalah pragmatik sistemik, pragamatik umum, pragmatik dalam perspektif kultur spesifik, dan masih beberapa lagi jenis-jenis pragmatik yang dikembangkan secara interdisipliner dan multididisipliner (Wilson, 2017). Salah satu dari banyak jenis pragmatik yang belum disebutkan itu adalah pragmatik siber. Pragmatik siber berkembang sebagai respons atas perkembangan bahasa dalam konteks perkembangan teknologi informasi, teknologi digital, dan teknologi internet
(Locher, 2013). Dengan perkembangan teknologi-teknologi tersebut bahasa tidak dapat lagi diintepretasi maksudnya dengan menggunakan perspektif lama. Artinya, pasti terdapat dimensi-dimensi bahasa yang tidak terjangkau dan tidak terjamah jika yang diperantikan adalah pragmatik dalam perspektif konvensional seperti yang disebutkan di depan itu.

Dalam pragmatik siber, sumber data bukan ditemukan dari bahasa natural manusia dalam tuturan keseharian bersemuka, tetapi sumber data substantif itu bersifat maya. Bukan hasil pertemuan bersemuka antara penutur dan mitra tutur, melainkan pertemuan yang bersifat maya lewat peranti teknologi yang disebut dengan 'gajet pintar'. Adapun sumber data lokasional dalam penelitian-penelitian berperspektif pragmatik siber adalah media-media sosial, seperti Twitter, Instagram, Website, Blog, dan masih banyak lagi yang lainnya (Locher, 2015). Memang sangat jelas perbedaan antara pragmatik dalam pengertian konvensional dengan pragmatik dalam pengertian siber (cyber-pragmatics). Di dalam pragmatik siber juga sangat kental dikenalkan konsep komunitas virtual (virtual community). Setiap orang yang memiliki akses ke dalam telepun pintar, masing-masing masuk ke dalam jejaring yang lalu disebut sebagai komunitas maya atau komunitas virtual itu (Yus, 2003) (Indrayani \& Johansari, 2019).

Tanpa harus mengerti siapa identitas dari otang yang bersangkutan, orang seolah-olah bisa bertutur, bersapa, berkomunikasi, antara satu dengan yang lainnya. Di satu sisi komunitas virtual demikian ini positif karena dapat 
menjadi wadah dari setiaop orang tanpa harus dikendalai oleh latar belakang apa pun, entah jenis kelamin, entah etnis, entah sosial, atau latar belakang yang lainnya. Jadi, setiap orang serasa bebas dan tidak berbatas dalam berelasi dengan sesamanya. Akan tetapi, di sisi yang lain dengan kebebasan berelasi yang tanpa ikatan itu, pelanggaranpelanggaran etika dalam berkomunikasi menjadi sangat sering terjadi (Burger, 2014), (Wilson, 2003). Pemerantian bahasa yang sesungguhnya tidak boleh lepas dari pertimbangan etika dan sosial-budaya, kadangkala lepas sama sekali sehingga yang terjadi adalah pendisfungsian dari hakikat bahasa. Keberingasan dan ingar-bingar sosial terjadi karena pemakaian bahasa yang tidak sesuai dengan fungsi hakikinya.

Secara singkat dapat dinyatakan kembali bahwa pragmatik siber itu sesungguhnya manifestasi dari perkembangan pragmatik yang bersifat multidisipliner, bahkan suatu saat bisa berubah menuju transdisipliner (Kecskes, 2012). Aspek-aspek luar kebahasaan dalam linguistik berpadu dengan teknologi informasi, khususnya teknologi digital dan teknologi internet. Aspek-aspek di dalam pragmastik sistemik, pragmatik umum, dan pragmatik kultur spesifik tetap kelihatan di dalam pragmatik siber, tetapi kehadiran aspek-aspek virtual sangat menentukan kejatian pada jenis pragmatik yang terakhir ini. Konsekuensinya, konteks eksternal dalam pragmatik juga dipilah menjadi dua jenis konteks, yakni konteks eksternal konvensional dan konteks eksternal virtual. Dalam pragmatik siber digunakan konteks eksternal virtual (virtual external context), bukan pertama-tama konteks eksternal konvensional, sekalipun sesungguhnya elemen-elemen di kedua jenis konteks itu serupa.

Perlu disampaikan bahwa konteks eksternal virtualberbeda dengankonteks eksternal konvensional dalam hal aspek-aspek dari setiap elemen konteks tersebut. Ambillah contoh elemen situasi ujar dalam konteks situasi yang disampaikan Geoffrey N. Leech (1983). Elemen situasi tuturan di era sekarang sudah barang tentu sangat berbeda dengan masa-masa ketika pragmatik umum dan pragmatik dalam perspektif kultur spesifik berkembang (SpencerOatey \& Jiang, 2003), (Zamzani, et al., 2017). Pada saat itu libatan teknologi digital dan teknologi internet belum banyak muncul sehingga bahasa dapat dimaknai dengan relatif mudah dan tidak mengandung kompleksitas yang berlebih seperti yang terjadi sekarang ini. Penulis mau menegaskan bahwa memaknai konteks situasi tutur tanpa mempertimbangkan libatan teknologi informasi dan teknologi internet terhadap bahasa adalah tindakan yang keliru. Jadi wujud kebahasaan yang ada sekarang ini muncul dalam berbagai wahana, mungkin juga dalam wahana ujaran kebencian (hate speech) atau mungkin dalam wahana berita palsu (hoax), selalu tidak dapat lepas dari dampak teknologi. Dalam kaitan dengan hal ini, perspektif pragmatik siber memiliki peran penting. Peran konteks eksternal virtual juga demikian, memiliki peran dan fungsi yang sangat menentukan (Mey, Brown, \& Mey, 2006).

Teori yang perlu disebut terakhir sebagai kerangka referensi (frame of reference) dan sebagai alat analisis (tools 
of analysis) di dalam penelitian ini adalah teori tentang tindak tutur perlokusi. Tindak tutur perlokusi dimaknai sebagai 'the act of affecting someone' atau tindak mempengaruhi orang lain. Perlokusi itu persoalan 'pengaruh' atau persoalan 'dampak'. Maksudnya adalah pengaruh atau dampak sebuah tindak berbahasa terhadap seseorang. Kalau ada tuturan 'Hei....nak, diam!! Bapak sudah pulang!'. Tuturan di atas bukan berbicara tentang kenyataan bahwa Bapak sudah pulang dari tempat tertentu, mungkintempatkerjaatauyang lain. Kalau kenyataan itu yang terjadi, hal tersebut hanyalah sebuah lokusi, yakni 'the act of informing something'. Lokusi adalah tindak menyampaikan atau menginformasikan sesuatu kepada orang lain (Wijana, 2014), (Zamzani et al., 2017).

Berbeda lagi jika dengan tuturan itu dimaksudkan untuk menyuruh seseorang melakukan sesuatu, atau 'the act of doing something', misalnya saja 'membuatkan minum sang ayah' atau tindakan yang lain, maka tindak berbahasa itu disebut sebagai tindak ilokusi. Jadi sebuah tuturan itu sesungguhnya dapat memiliki tiga kemungkinan intepretasi maksud dalam perspektif J. L. Austin, yakni lokusioner, ilokusioner, dan perlokusioner (Mey, 2004), (Zamzani et al., 2017). Pakar lain seperti Searle, Kreider, dan Holmes, lalu memerinci tindak ilokusi ke dalam jenis-jenis tindakan ilokusi (Sperber \& Wilson, 2012) yang dapat diketahui dari jenis-jenis verba yang digunakan dalam bertutur tersebut. Akan tetapi, tindak perlokusioner tidak diperinci lebih lanjut oleh para pakar linguistik dan pragmatik.
Perlokusi yang berbicara masalah 'pengaruh' atau 'dampak' seperti lepas dari perhatian para linguis karena hal tersebut berkaitan dengan perspektif di luar bahasa itu sendiri, yakni perspektif komunikasi dan bisnis (Kuhn, 1984). Sebagai contoh adalah iklan komersial tertentu di televisi. Iklan tersebut dapat diukur dampak atau pengaruhnya terhadap daya beli masyarakat. Semakin dampak terhadap day abeli masyarakat itu semakin besar, maka semakin besarlah dampak perlokusi iklan tersebut. Sebaliknya, jika pengaruh atau dampak itu kecil maka semakin kecillah dampak perlokusi iklan komersial itu. Seorang peneliti akan dapat menentukan besar-kecilnya pengaruh atau dampak perlokusi dari sesuatu dengan menentukan parameter berskala (Kuhn, 1984).

Dalam penelitian ini, pengaruh atau dampak dari hoaks Covid-19 akan dilihat dengan cermat, bukan untuk mengetahui besar-kecilnya dampak, melainkan untuk mengetahui manifestasi dampak itu dalam kaitan dengan maksud penyebaran hoaks tersebut. Pertimbangan konteks eksternal virtual sangat penting dilakukan untuk menentukan maksud yang tepat dari setiap manifestasi dampak perlokusi (Taguchi, 2015).

Tujuan pokok dari penelitian ini adalah untuk mendeskripsikan dampak atau pengaruh perlokusi berita palsu Covid-19 yang beredar di media sosial. Perspektif yang digunakan dalam penelitian ini adalah perspektif Cyber-pragmatics berbantuan konteks eksternal virtual (Kramsch, 2002). Hasil penelitian ini akan sangat bermanfaat untuk menumbuhkan kesadaran kritis warga masyarakat yang setiap hari 
terhantam oleh badai hoaks Covid-19. Selain itu, secara teoretis penelitian ini juga akan mengembangkan ilmu pragmatik, khususnya Cyberpragmatics yang terbukti belum berkembang optimal di seluruh dunia ini, apalagi dalam percaturan linguistik-pragmatik di Indonesia.

\section{METODE}

Pendekatan penelitian yang diterapkan dalam penelitian ini adalah pendekatan deskriptif kualitatif. Diterapkan pendekatan ini karena tujuan penelitian ini bukanlah memverifikasi teori (kualitatif-verifikatif), dan bukan pula untuk membangun generalisasi sehingga terumuskan teori (kualitatif-grounded), melainkan untuk mendeskripsikan fenomena bahasa yang terjadi dalam masyarakat (Martin, 1995), khususnya terkait dengan hoaks Covid-19.

Objek sasaran penelitian ini adalah manifestasi perlokusi hoaks Covid-19. Data penelitian ini adalah cuplikan-cuplikan tuturan yang di dalamnya terdapat manifestasimanifestasi perlokusi hoaks Covid-19 di media sosial. Sumber data substantif penelitian ini adalah teks-teks tertulis yang terdapat di media sosial yang di dalamnya terdapat manifestasimanifestasi perlokusi hoaks Covid-19. Adapun sumber data lokasionalnya adalah media-media sosial seperti Instagram, Facebook, Blog, Webs, dll., yang hadir di sekitar waktu pelaksanaan penelitian (Mahsun, 2005).

Data dikumpulkan dengan metode simak. Metode simak dilakukan dengan cara melaksanakan penyimakan terhadap sumber data. Adapun jenis metode simak yang digunakan tersebut adalah metode simak bebas libat cakap. Teknik yang digunakan dalam menerapkan metode simak di atas adalah teknik rekam dan teknik catat. Data yang telah terkumpul selanjutnya diinventirasisasi, diseleksi, diklasifikasi, ditipifikasi, dan selenjutnya dianalisis (Sudaryanto, 2016).

Sebelum dilakukan analisis data, validatas data dipastikan terlebih dahulu dengan menerapkan triangulasi data, baik kepada pakar terkait maupun kepada teori-teori yang relevan. Metode analisis data yang diterapkan adalah metode analisis ekstralingual atau metode analisis padan yang bersifat ekstralingual. Adapun teknik yang diterapkan dalam rangka menerapkan metode analisis data tersebut adalah teknik hubung banding khususnya teknik hubung banding yang bersifat menyamakan (Mahsun, 2005). Selanjutnya, hasil analisis data disajikan dengan metode sajian informal yang menggunakan kata-kata biasa.

\section{HASIL DAN PEMBAHASAN Hasil}

Dari data yang telah dikumpulkan denganbaik, diklasifikasidanditipifikasi, serta ditriangulasikan dengan baik pula kepada pakar terkait dan terhadap teoriteori yang relevan, maka data dianalisis dengan menerapkan metode dan teknik tertentu untuk menghasilkan temuan dampak-dampak perlokusi hoaks Covid-19 dengan hasil sebagai berikut. 
Tabel 1. Dampak Perlokusi Hoaks

\begin{tabular}{|c|c|c|}
\hline Kode Data & Wujud Tuturan & Dampak Perlokusi \\
\hline $\begin{array}{l}\text { Data } 1 \\
\text { Hoaks } \\
\text { Covid-19 }\end{array}$ & $\begin{array}{l}\text { Apa Benar Pemerintah Indonesia Hanya Melarang } \\
\text { Masuknya Pendatang dari Iran, Italia, Serta } \\
\text { Korea Selatan dan Membiarkan Masuknya } \\
\text { Warga Cina? https://www.instagram.com/p/ } \\
\text { B91OV6sgVew/?utm_source=ig_web_button_share_ } \\
\text { sheet }\end{array}$ & $\begin{array}{l}\text { Perlokusi Mengentalkan } \\
\text { Rasa Sentimen }\end{array}$ \\
\hline $\begin{array}{l}\text { Data } 2 \\
\text { Hoaks } \\
\text { Covid-19 }\end{array}$ & $\begin{array}{l}\text { Apa benar masker dari tisu basah efektif dalam } \\
\text { menangkal penularan virus Corona Covid-19? } \\
\text { https://www.instagram.com/p/ } \\
\text { B9V23AVAVP8/?utm_source=ig_web_button_share_ } \\
\text { sheet }\end{array}$ & $\begin{array}{l}\text { Perlokusi Menumbuhkan } \\
\text { Persepsi Keliru }\end{array}$ \\
\hline $\begin{array}{l}\text { Data } 3 \\
\text { Hoaks } \\
\text { Covid-19 }\end{array}$ & $\begin{array}{l}\text { Benarkah Kementrian Kesehatan Menetapkan } \\
\text { Zona Kuning Terkait Virus Corona? https:// } \\
\text { www.instagram.com/p/B9VwYWEHNSc/?utm_ } \\
\text { source=ig_web_button_share_sheet }\end{array}$ & $\begin{array}{l}\text { Perlokusi Menyindir } \\
\text { Otoritas }\end{array}$ \\
\hline $\begin{array}{l}\text { Data } 4 \\
\text { Hoaks } \\
\text { Covid-19 }\end{array}$ & $\begin{array}{l}\text { Setelah Inggris, Kini Warga Belanda Ikut Bakar } \\
\text { Tower 5G } \\
\text { https://www.facebook.com/nawalakarsa/photos/a.1 } \\
\text { 47661272256627/1096284667394278/?type=3 }\end{array}$ & $\begin{array}{l}\text { Perlokusi Menumbuhkan } \\
\text { Kegaduhan }\end{array}$ \\
\hline $\begin{array}{l}\text { Data } 5 \\
\text { Hoaks } \\
\text { Covid-19 }\end{array}$ & $\begin{array}{l}\text { Pasar Tebet Barat Ditutup Total Karena Ada } \\
\text { Pedagang Positif Corona } \\
\text { https://www.instagram.com/p/B_ } \\
\text { ADSY0FQi3/?utm_source=ig_web_button_share_ } \\
\text { sheet }\end{array}$ & $\begin{array}{l}\text { Perlokusi Menebar } \\
\text { Ketakutan }\end{array}$ \\
\hline $\begin{array}{l}\text { Data } 6 \\
\text { Hoaks } \\
\text { Covid-19 }\end{array}$ & $\begin{array}{l}\text { Wanita Hamil Lebih Beresiko Terkena Covid-19 } \\
\text { https://www.instagram.com/p/B-_- } \\
\text { UTDqFeiv/?utm_source=ig_web_button_share_sheet }\end{array}$ & $\begin{array}{l}\text { Perlokusi Menumbuhkan } \\
\text { Kekhawatiran }\end{array}$ \\
\hline $\begin{array}{l}\text { Data } 7 \\
\text { Hoaks } \\
\text { Covid-19 }\end{array}$ & $\begin{array}{l}\text { Benar Ada Penumpang yang Meninggal di T3 } \\
\text { Bandara Soekarno-Hatta karena Virus Corona? } \\
\text { https://www.instagram.com/p/B70i2iMg5vJ/?utm_ } \\
\text { source=ig_web_button_share_sheet }\end{array}$ & $\begin{array}{l}\text { Perlokusi Menumbuhkan } \\
\text { kasak-kusuk }\end{array}$ \\
\hline
\end{tabular}

\section{Pembahasan}

Pada bagian berikut ini, setiap dampak perlokusi yang disampaikan pada Tabel 1 di atas dibahas satu persatu.

\section{Perlokusi Mengentalkan Rasa Sentimen}

Bahwa pemerintah yang berkuasa sekarang ini distigmatisasi dekat dengan pemerintah Cina sudah tidak menjadi rahasia publik. Stigmatisasi itu tentu saja dilakukan oleh mereka-mereka yang berada pada posisi berseberangan dengan pemerintah. Dengan berbagai cara, mereka menebar berita bohong, berita palsu, terkait dengan hubungan antara Cina dan Indonesia. Tentu saja hal yang demikian ini tidak dapat lepas dari fakta sosial masa lampau pada awal masa pemerintahan Orde Baru. Singkat kata, Indonesia memiliki sejarang yang tidak cerah dalam kaitan hubungan dengan Cina. Nah, dalam berita hoaks pada Data 1 Hoaks Covid- 
19 di bawah ini, 'Apa Benar Pemerintah Indonesia Hanya Melarang Masuknya Pendatang dari Iran, Italia, Serta Korea Selatan dan Membiarkan Masuknya Warga Cina?', stigma-stigma tersebut dicuatkan lagi oleh si pembuat hoaks. Bentuk 'membiarkan warga Cina' dalam cuplikan tuturan tersebut sangat kentara bahwa stigma masa lalu tersebut hendak dicuatkan. Dalam perspektif pragamatik umum, hal tersebut tidak dapat ditangkan sebagai akibat dari pemerantian konteks eksternal konvensional. Aspek-aspek konteks eksternal perlu dijabarkan lebih lanjut dengan mendekatkan perkembangan teknologi informasi, teknologi digital, dan teknologi internet, sehinga dimensidimensi virtual terkait dengan konteks eksternal tersebut dapat dijangkau.

Dari implementasi perspektif cyberpragmatics dengan pemerantian konteks eksternal virtual itulah perlokusi mengetalkan rasa sentimen itu menjadi jelas (Yus, 2011). Dimensi perlokusi tidak sama sekali kelihatan dalam wujud tuturan atau wujud beritanya, melainkan terletak pada dampak dari pemunculan stigma Cina tersebut. Berkaitan dengan hal ini, Data 1 Hoaks Covid-19 berikut ini dapat dicermati dan dibaca lebih lanjut.

\section{Data 1 Hoaks Covid-19}

Apa Benar Pemerintah Indonesia Hanya Melarang Masuknya Pendatang dari Iran, Italia, Serta Korea Selatan dan Membiarkan Masuknya Warga Cina? https://www. instagram.com/p/B910V6sgVew/?utm source $=$ ig web button share sheet

Konteks: Dalam berita via instagram tempo, pada 11 Maret 2020 terkait pemerintah Indonesia hanya melarang masuknya pendatang dari Iran, Italia, serta Korea Selatan dan membiarkan masuknya warga Cina merupakan berita hoax. Berita ini sebelumya banyak tersebar di media daring dan media tempo berusaha melakukan penelurusan lanjutan. Berdasarkan pemeriksaan fakta Tempo sebelum adanya larangan masuk pendatang dari Iran, Italia, dan Korea Selatan, pembatasan masuknya pendatang dari Cina telah dilakukan lebih awal oleh pemerintah, yakni pada 5 Februari 2020. Selain menghentikan penerbangan dari dan ke Cina, pemerintah juga menghentikan sementara penerbitan visa bagi warga Cina.

\section{Perlokusi Menumbuhkan Persepsi Keliru}

Hoaks atau berita palsu selalu bersifat persuasif. Tujuan dari persuasi adalahuntukmembujukdanmenggiring publik untuk meyakini berita yang dimaksudkan oleh si pembuat hoaks tersebut. Penggiringan opini publik pada Data 2 Hoaks Covid-19 berikut ini terletak pada penyampaian informasi yang berbunyi, 'Apa benar masker dari tisu basah efektif dalam menangkal penularan virus Corona Covid-19?'. Seolah-olah saja orang tersebut bertanya terkait dengan kebenaran informasi bahwa masker dan tisu basah efektif mengakal virus. Sesungguhnya si pembuat hoaks sendiri mengerti bahwa jawabannya adalah 'tidak'. Akan tetapi, didorong oleh tujuan 'menumbuhkan persepsi publik agar keliru', maka engan tuturan tersebut si pembuat hoaks 
ingin menggiring pendapat masyarakat bahwa hal-hal tersebut dapat digunakan untuk menangkal virus covid-19. Peneliti hendak mengatakan bahwa perlokusi menumbuhkan persepsi keliru itu adalah dampak, pengaruh, bukan maksud itu sendiri. Oleh karena itu, 'menumbuhkan persepsi keliru' bukanlah maksud, melainkan dampak atau pengaruh. Cyber-pragmatics sebagai perspekti penelitian sangat tepat digunakan untuk memaknai berita palsu demikian ini (Yus, 2011).

Dampak perlokusi berita akan dapat ditemukan dengan mudah manakala aspek-aspek dalam elemen konteks eksternal konvensional diperinci lebih lanjut sehingga berjatidiri konteks eksternal virtual. Cuplikan tuturan Data 2 Hoaks Covid-19 berikut ini dapat dicermati lebih lanjut untuk memperjelas hal ini.

\section{Data 2 Hoaks Covid-19}

Apa benar masker dari tisu basah efektif dalam menangkal penularan virus Corona Covid-19?

https://www.instagram.com/p/ B9V23AVAVP8/?utm source $=$ ig web button share sheet

Konteks: Berdasarkan berita via instagram Tempo pada 4 Maret 2020 yang menyatakan bahwa penggunaan masker dari tisu basah efektif dalam menangkal penularan virus Corona Covid-19 adalah berita yang hoax. Hal ini didukung oleh pendapat beberapa pakar yang menyatakan bahwa bahan tisu yang basah tersebut malah membuat debu dan kotoran lebih mudah menempel. Bakteri pun bisa saja menempel di tisu basah dan berpindah ke lokasi baru, salah satunya saluran pernapasan. Masyarakat dianjurkan untuk terus mencuci tangan dan penggunaan masker diwajibkan bagi yang sakit saja. Penjelasan ini diharapkan dapat memberikan informasi terbaru dan akurat terkait penanganan virus corona.

\section{Perlokusi Menyindir Otoritas}

Semakin tinggi pohon semakin berbahayalah pohon itu akan terpaan angin ribut. Demikian pula semakin tinggi jabatan seseorang semakin riskanlah orang tersebut oleh terpaanterpaan berbagai persoalan, termasuk dijadikan objek di dalam sebuah berita hoaks. Orang Jawa mengatakan 'entekgolek, kurang amek', yang artinya adalah 'tidak pernah berhenti mencarikan kesalahan seseorang' jika orang tersebut memang disasar untuk dijadikan objek cercaan dan penghinaan. Hoaks selalu berorientasi pada cercaan dan penghinaan tersebut untuk semakin menstigmatisasi identitas seseorang, pejabat tertentu, dan semacamnya. Dalam kaitan dengan hal tersebut tuturan yang berbunyi, 'Benarkah Kementrian Kesehatan Menetapkan Zona Kuning Terkait Virus Corona?' bukanlah semata-mata pertanyaan. Secara lokutif bentuk kebahasaan itu semata-mata sebuah pertanyaan. Akan tetapi secara perlokutif (Kuhn, 1984), dampak atau pengaruh dari tuturan itulah yang hendak disampaikan oleh penyusun dan penyebar hoaks. Konteks eksternal virtual sangat menentukan manifestasi perlokusi hoaks untuk cuplikan berita pada Data 3 Hoaks Covid-19 yang selengkapnya dapat dicermati berikut ini. 
Data 3 Hoaks Covid-19

Benarkah Kementrian Kesehatan
Menetapkan Zona Kuning Terkait Virus
Corona? https://www.instagram.com/p/
B9VwYWEHNSc/?utm source=ig web
button share sheet
Konteks: Berita yang dimuat dalam media
instagram antarnews.com pada tanggal
14 Maret 2020 ini nyatanya merupakan
berita hoax yang dikirim secara berantai via
whatsup tentang Info kemkes 6 kota zona
kuning corona: Medan, Batam, Jakarta,
Surabaya, Bali dan Manado. Merebaknya
berita zona kuning corona ini muncul sering
bertambahnya jumlah korban yang ada di
Indonesia, namun setelah ditelusuri oleh
media antaranews.com ditemukan fakta
bahwa informasi itu tidaklah benar. Hal ini
didukung olehpernyataanDirjenpencegahan
dan penyakit Anung Suguhantono yang
mengklim bahwa Kementerian tidak pernah
mengeluarkan infomasi zona kuning terkait
kewaspadaan virus corona.

\section{Perlokusi Menumbuhkan Kegaduhan}

Kegaduhan merupakan salah satu tujuan pokok dari penyusunan dan penyebaran hoaks. Ketika masyarakat gaduh, kesadaran kritis dan rasionalitas masyarakat biasanya turun dengan sangat dramatis. Orang tidak lagi mudah melihat mana yang betul dan man ayang salah, dan yang terjadi adalah kelompok sosial yang gaduh dan beringas, lari ke sana dan kemari. Orang Jawa mengatakan 'rubuh-rubuh gedhang' atau 'ikut-ikutan'. Kalau sekelompok orang merusak, semua orang ikut merusak. Ketika sekelompok orang menciptakan kekerasan, semua orang ikut melakukan kekerasan. Jadi, sama sekali tidak ada habitus baru, habitus yang berani melawan arus. Dalam cuplikan tuturan pada Data 4 Hoaks Covid-19 berikut ini, potensi untuk menumbuhkan kegaduhan itu terletak pada tuturan, 'Setelah Inggris, Kini Warga Belanda Ikut Bakar Tower 5G'. Berita bohong demikian itu dapat memberikan semacam legitimasi bagi banyak orang untuk melakukan hal serupa. Jadi lazimnya kegaduhan yang satu akan menular pada kegaduhan yang berikutnya. Bahasa yang digunakan dalam kegaduhan biasanya bersifat beringas, jauh dari fungsi hakiki bahasa yang selama ini telah dipahami banyak orang, yakni sebagai peranti pengembang akal budi dan pengukuh kerja sama antarsesama (Sudaryanto, 2015).

Alih-alih pengukuh kerja sama, bahasa dijadikan wahan auntuk merusak hubungan antar sesama. Jadi dampak perlokusi dari tuturan seperti yamng disampaikan pada Data 4 Hoaks Covid-19 itu sangat besar dan perlu diwaspadai. Data berikut dapat diperhatikan dalam kaitan denga dampak perlokusi ini. 


\section{Data 4 Hoaks Covid-19}

Setelah Inggris, Kini Warga Belanda Ikut Bakar Tower 5G

https://www.facebook.com/nawalakarsa/ photos/a.147661272256627/109628466739 4278/?type $=3$

Konteks: Dalam berita yang dikutip dari media fecebook Nawalakarsa 13 April 2020 telah tersebar sebuah berita hoax bahwa virus korona mampu menular melalui jaringan 5G. Beberapa tower 5G di kota Rotterdam, Liessel, Beesd dan Nuenen rusak dan ludes dibakar oleh warganya sendiri. Berita terkait penularan virus corona melalui jaringan $5 \mathrm{G}$ dibantah oleh WHO yang diklaim bahwa virus korona tidak menular melalui saluran radio atau bahkan jaringan 5G. Hal itu dikarenakan virus tidak dapat menjalar melalui sinyal radio atau pun jaringan $4 \mathrm{G}$ atau bahkan $5 \mathrm{G}$. WHO juga menambahkan bahwa virus korona hanya akan menular melalui droplet dari orang yang sudah terjangkit virus tersebut. Virus ini akan menginfeksi saluran pernafasan melalui droplet dari orang yang batuk, bersin, dan percakapan tatap muka. Dengan demikian semua hoax terkait penyebaran melalui jaringan 5G tidak benar adanya, masyarakat diharapkan lebih bijak menyaring informasi dan tidak menyikapi berita dengan cara yang salah.

\section{Perlokusi Menebar Ketakutan}

Siapa yang tidak takut dengan kematian. Jika ditanyakan kepada warga masyarakat sudah barang tentu jawaban untuk pertanyaan itu adalah bahwa semua orang khawatir dengan kematian. Jangankan kematian, rasa sakit saja ditakuti dan dihindari oleh semua orang. Oleh karenanya, setiap orang segera berobat kalau dirinya merasa sakit. Kenyataan tentang 'rasa takut' atau 'rasa khawatir' ini dimanfaatkan oleh pembuat dan penyebar hoaks. Oleh karena itu, hoaks yang bertujuan untuk menebarkan ketakutan ini dikreasi dan ditebarkan. Dalam cuplikan tuturan pada Data 5 Hoaks Covid-19 ini, modus menakutnakuti itu berupa tuturan yang berbunyi, 'Pasar Tebet Barat Ditutup Total Karena Ada Pedagang Positif Corona.' Menumbuhkan rasa takut jelas sekali tidak sejalan dengan mengupayakan peningkatan akal budi karena sesungguhnya seseorang akan dapat meningkatkan akal budinya kalau dia berani menggunakan atau memerantikan bahasa dengan baik. Bekerja sama dengan sesama sebagai salah satu tujuan yang hakiki dari orang berbahasa juga tidak akan dapat tercapai jika rasa takut dibentuk.

PadazamankolonialBelandazaman dahulu masyarakat selalu dipersalahkan supaya memiliki rasa takut yang tinggi. Teror menakutkan disampaikan kepada masyarakat dengan dibentak-bentak, ditendang-tendang, dan terbukti bahwa pada saat itu kesadaran kritis warga masyarakat kita jatuh tersungkur. Akhirnya, masyarakat dan bangsa kita mudah diperdayakan dan dipaksa untuk bekerja keras, bekerja rodi, membangun jalan, membangun jembatan, membuat jalan kereta, bertanam paksa, dan seterusnya. Semuanya itu adalah bukti bahwa penciptaan ketakutan sebagai perlokusi sungguh-sungguh tidak boleh dilakukan oleh para pembuat dan penyebar berita palsu atau hoaks. Data 5 Hoaks Covid-19 berikut dapat dicermati lebih lanjut berkaitan dengan hal ini. 
Data 5 Hoaks Covid-19

Pasar Tebet Barat Ditutup Total Karena Ada Pedagang Positif Corona

https://www.instagram.com/p/B ADSY0FQi3/?utm source=ig web button share sheet

Konteks: Berita tentang pasar tebet barat ditutup total karena ada pedagang posistif corona yang dimuat dalam media instagram Turnbackhoaxid pada Rabu, 15 April 2020 ini nyatanya merupakan berita hoax yang tersebar di media sosial. Dalam pesan itu juga disebutkan bahwa terdapat dua orang karyawan toko yang positif dan 12 orang lainnya suspek. Berita tersebut akhirnya ditelusuri lewat hasil wawancara dengan Camat Tebet, Jakarta Selatan, Dyan Airlangga yang secara tegas membantah kabar penutupan pasar disebabkan adanya pedagang yang terpapar COVID-19. Lebih lanjut dijelaskan bahwa ketiga pasar yang terdapat di wilayah Tebet, yaitu Tebet Barat, Tebet Timur dan Bukit Duri tetap beroperasi melayani sejak awal pandemi corona untuk memenuhi kebutuhan pokok. Informasi ini disampaikan agar masyarakat dapat memperoleh infromasi yang jelas dan tepat.

\section{Perlokusi Menumbuhkan Kekhawatiran}

Rasa khawatir adalah salah satu perlokusi hoaks atau berita palsu. Berita bohong terkait dengan Covid-19 yang sekarang telah menjadi pandemi ini semakin hari semakin tinggi, apalagi dengan fakta terus meningkangkatnya pasien positif dan meninggal dunia di mana-mana. Hal tersebut bukan saja terjadi di Indonesia, tetapi juga terjadi di berbagai negara di seluruh dunia. Orang yang khawatir tentu menjadi sangat rentan ketahanan tubuhnya. Daya tahan tubuh yang rentan pada akhirnya akan berakibat buruk pada diri seseorang. Dalam kelompok besar, kekhawatiran terhadap sesuatu juga lazimnya menghadirkan keresahan dan ketakutan akan sesuatu yang memberatkan, mencelakakan, membuat menderita, dan seterusnya. Pada cuplikan Data 6 Hoaks Covid19 berikut ini, bentuk kebahasaan yang diperantikan untuk membangun perlokusi kekhawatiran tersebut adalah, 'Wanita Hamil Lebih Beresiko Terkena Covid-19'. Penumbuhan rasa khawatir dalam kaitan dengan fungsi bahasa merupakan salah satu wujud dari pengawafungsian bahasa (Sudaryanto, 2016).

Dalam konteks siber, perspektif pragmatik yang tepat digunakan untuk mengintepretasi maksud dan dampak dari tuturan-tuturan terkait hoaks Covid-19 adalah cyber-pragmatics berbantuak konteks eksternal virtual. Data hoaks berikut ini baik dicermari lebih lanjut untuk memahami dampak perlokusi menumbuhkan kekhawatiran ini.

\section{Data 6 Hoaks Covid-19}

Wanita Hamil Lebih Beresiko Terkena
Covid-19
https://www.instagram.com/p/B-
UTDqFeiv/?utm source=ig web button
share sheet
Konteks: Berita yang menyatakan bahwa
ibu hamil lebih beresiko tekena Covid-
19 diberitakan dalam media instagram
Hoaxbustercovid19 pada Selasa, 15 April
2020 merupakan salah satu berita hoax yang
banyak beredar di media sosial akhir-akhir
ini. Setelah ditelusuri, WHO menjelaskan
saat ini belum terdapat kasus yang
membuktikan wanita hamil lebih beresiko
terhadap COVID-19, namun hal tersebut
mungkin terjadi dikarenakan perubahan
sistem imun pada ibu hamil. Test COVID-19
lebih diprioritaskan untuk ibu hamil dengan
gejala dan faktor risiko COVID-19. Dengan
demikian beita yang menyatakan bahwa ibu
Hamil Harus Tes Covid-19 merupakan hoax
dan tidak mendasar.




\section{Perlokusi Menumbuhkan kasak-kusuk}

Kasak-kusuk merupakan salah satu dampak dari penyebaran berita bohong. Berita bohong lazimnya memiliki tingkat ketepatan makna dan maksud yang sangat rendah. Terlebihlebih kalau si pembuat berita bohong itu sudah sangat berpengalaman dalam memerantikan bahasa untuk kepentingan yang tidak baik itu. Maka dari itu, ketidaktepatan menjadi cikalbakal bertumbuhnya kegaduhan karena setiap orang memiliki persepsi berbeda tentang substansi berita bohong tersebut. Jelas sekali bahwa kasakkusuk yang isa bertumbuh menjadi kegaduhan itu bertentangan dengan hakikat bahasa dan fungsi hakiki bahasa. Dalam cuplikan berita bohong berikut ini, sumber kasak-kusuk itu adalah, 'Benar Ada Penumpang yang Meninggal di T3 Bandara SoekarnoHatta karena Virus Corona?' Adanya berita kematian orang terkait dengan sebab-sebab tertentu, padahal penyebab kematian seseorang yang ditebarkan itu keliru sudah barang tentu merusak kesadaran kritis masyarakat.

Spekulasi ini dan itu menjadi liar sekali bertumbuh, dan dalam kondisi demikian itu rasionalitas seseorang atau sekelompok orang dapat dengan mudah diperdayakan. Cuplikan tuturan pada Data 8 Hoaks Covid-19 ini perlu dicermati lebih lanjut untuk lebih memahami perlokusi ini (Kuhn, 1984).

\section{Data 7 Hoaks Covid-19}

Benar Ada Penumpang yang Meninggal di T3 Bandara Soekarno-Hatta karena Virus Corona?

https://www.instagram.com/p/ B70i2iMg5vJ/?utm source=ig web button share sheet

Konteks: Berita yang dimuat dalam media instagram milik Tempo pada 27 Januari 2020 ini nyatanya adalah berita hoax yang dikirim secara berantai via whatsapp yang menyatakan bahwa ada penumpang yang meninggal di T3 Bandara SoekarnoHatta karena virus corona. Berita tersebut kemudian ditelusuri oleh pihak Tempo melalui wawancara dengan Senior Manager of Branch Communication and Legal Soekarno-Hatta dan diperoleh fakta bahwa pada 26 Januari 2020 benar ada penumpang yang meinggal di T3 bandara SoekarnoHatta namun korban meninggal dinyatakan meninggal bukan karena virus corona melainkan akibat gagal jantung.

Hasil analisis yang telah dilakukan terhadap data penelitian ini telah menghasilkan tujuh makna perlokusi. Perlokusibertautandengandampakatau pengaruh dari sebuah tuturan terhadap sesuatu. Jadi perlokusi itu tataran yang ada satu tingkat lebih rumit dari sekadar maksud. Makna pragmatik atau maksud bersentuhan dengan tindak ilokusi dalam pragmatik. Adapun dampak atau pengaruh itu bersentuhan dengan perlokusi dalam tindak tutur pragmatik (Hassall, 2012). Persoalan dampak atau pengaruh dalam tindak perlokusi jarang digarap di dalam penelitian karena bahasa memang lazimnya berfokus pada tindak lokusi dan tindak ilokusi. Persoalan dampak atau pengaruh tuturan lazimnya digaram dalam bidang ilmu lain, yakni bidang komunikasi. Pengaruh dari iklan televisi tentang kosmetik tertentu, misalnya, digarap 
dalam konteks komunikasi dan bisnis. Iklan yang sama digarap oleh bahasa terutama dalam kaitan dengan makna lokutif dan mankan ilokutifnya. Satu hal lagi yang perli disampaikan di sini bahwa hoaks Covid-19 yang bertebaran di media sosial selama ini dalam perspektik bahasa dapat digarap dengan cyber-pragmatics (Locher, 2013). Adapun konteks yang diperantikan dalam perspektif pragamtik baru yang tidak lepas dari teknologi internet ini adalah konteks eksternal virtual (Mey, 2003). Dengan perspektif cyber-pragmatics ini, penulis dapat menemukan tujuh manifestasi perlokusi.

\section{SIMPULAN}

Sejalan dengan rumusan masalah yang telah disampaikan pada bagian terdahulu, penelitian terhadap hoaks Covid-19 ini dilaksanakan dengan menempatkan perspektif cyberpragmatics. Perspektif pragmatik siber dilakukan dengan berbantuan konteks eksternal yang sifatnya virtual untuk menemukan dampak perlokusi tuturan hoaks Covid-19 yang betebaran di media sosial hingga sekarang. Penelitian berperspektif cyber-pragmatics ini telah menghasilkan tujuh dampak perlokusi hoaks Covid-19. Ketujuan dampak perlokusi hoaks Covid-19 tersebut disampaikan berturut-turut sebagai berikut: (1) perlokusi mengentalkan rasa sentimen; (2) perlokusi menumbuhkan perspepsi keliru; (3)perlokusi menyindir otoritas; (4) perlokusi menumbuhkan kegaduhan; (5) perlokusi menebar ketakutan; (7) perlokusi menumbuhkan kekhawatiran; (8) perlokusi menumbuhkan kasak-kusuk.

Sekalipun begitu, penelitian ini masih memiliki keterbatasan dalam hal ketersediaan data. Dalam penelitian lain yang lebih komprehensif, keterbatasan data tersebut akan diatasi oleh peneliti sehingga dampak perlokusi yang semakin banyak akan dapat ditemukan. Dengan ditemukannya dampak perlokusi tersebut, kesadaran kritis masyarakat akan terbantu terbangun kembali dalam menghadapi semakin banyaknya hoaks yang beredar di media sosial.

\section{DAFTAR PUSTAKA}

Burger, J. M. (2014). Obedience. In The Oxford Handbook of Social Influence. https://doi.org/10.1093/ oxfordhb/9780199859870.013.5

Chen, J. (2017). Research Trends in Intercultural Pragmatics. Australian Journal of Linguistics. https://doi.o $\mathrm{rg} / 10.1080 / 07268602.2016 .12049$ 03

Cyber, K. C. (2004). Karakteristik cerpen-cerpen, 190-203.

Handayani, T. K. (2016). Nilai-Nilai Karakter Dalam Tindak Tutur Ilokusi Dalam Buku Wir Besuchen Eine Moschee. Litera, 15(2), 305318. https://doi.org/10.21831/ltr. v15i2.11831

Hassall, T. (2012). Sociopragmatics is slower: A reply to Chang. Language Sciences. https://doi.org/10.1016/j. langsci.2011.12.001

Kecskes, I. (2012). Sociopragmatics and cross-cultural and intercultural studies. In The Cambridge Handbook of Pragmatics. https://doi.org/DOI: 10.1017/CBO9781139022453.033

Kramsch, C. (2002). Language and Culture: A Social Semiotic Perspective. Adfl. https://doi. org/10.1632/adfl.33.2.8 
Kuhn, E. D. (1984). Speech act theory and pragmatics. Journalof Pragmatics. https://doi.org/10.1016/03782166(84)90068-7

Locher, M. A. (2013). Cyberpragmatics: Internet-Mediated Communication in Context. Journal of Pragmatics. https://doi.org/10.1016/j. pragma.2012.12.002

Locher, M. A. (2015). Interpersonal pragmatics and its link to (im) politeness research. Journal of Pragmatics. https://doi. org/10.1016/j.pragma.2015.05.010

Mahsun, M. (2005). Metode Penelitian Bahasa. Jakarta: PT Raja Grafindo Persada. https://doi.org/10.1200/ JCO.2008.17.1991

Martin, T. (1995). Cultural Contexts. Ethics \& Behavior. https://doi. org/10.1207/s15327019eb0503_11

Mey, J. L. (2003). Context and (dis) ambiguity: A pragmatic view. Journal of Pragmatics. https:// doi .org / $10.1016 /$ S 0378 2166(02)00139-X

Mey, J. L. (2004). Pragmatics: An Introduction. Pragmatics. https://doi. org/10.1353/lan.2004.0045

Mey, J. L. L., Brown, K., \& Mey, J. L. L. (2006). Pragmatics: Overview. In Encyclodpedia of language and linguistics. https:// doi.org/10.1002/9781405198431. wbeal1338

Pranowo, P. (2020). Perspektif Masyarakat Jawa Terhadap Pemakaian Bahasa Nonverbal: Studi Kasus Etnopragmatik. Litera, 19(1), 52-71. https://doi.org/10.21831/ 1tr.v19i1.28873

Rahardi, R. K. (2017). Linguistic Impoliteness in The Sociopragmatic Perspective. Jurnal Humaniora. https://doi.org/10.22146/ jh.v29i3.24954

Sheira Ayu Indrayani dan Citra Aulia Johansari. (2019). Cyberbullying Use on Teenage Artists and Its Implications. Litera, 18(2), 275296.

Spencer-Oatey, H., \& Jiang, W. (2003). Explaining cross-cultural pragmatic findings: Moving from politeness maxims to sociopragmatic interactional principles (SIPs). Journal of Pragmatics. https:// doi .org / 10.1016 / S 0378 2166(03)00025-0

Sperber, D., \& Wilson, D. (2012). Pragmatics, modularity and mindreading. In Meaning and Relevance.https://doi.org/10.1017/ CBO9781139028370.016

Sudaryanto. (2015). Metode dan Aneka Teknik Analisis Bahasa: Pengantar Penelitian Wahana Kebudayaan secara Linguistis (1st ed.). Yogyakarta: Sanata Dharma University Press.

Sudaryanto. (2016). Metode dan Aneka Teknik Analisis Bahasa (1st ed.). Yogyakarta: Sanata Dharma University Press.

Taguchi, N. (2015). "Contextually" speaking: A survey of pragmatic learning abroad, in class, and online. System. https://doi.org/10.1016/j. system.2014.09.001

Wijana, I. D. P. (2014). Bahasa, Kekuasaan, Dan Resistansinya: Studi Tentang Nama-Nama Badan Usaha Di Daerah Istimewa Yogyakarta. Jurnal Humaniora.

Wilson, D. (2003). Relevance and lexical pragmatics. Pragmatics.

Wilson, N. (2017). Linguistic ethnography. In The Routledge Handbook of Language in 
the Workplace. https://doi. Zamzani, Z., Rahayu, Y. E., \& org/10.4324/9781315690001

Yus, F. (2003). Humor and the search for relevance. Journal of Pragmatics. https://doi.org/10.1016/S03782166(02)00179-0

Yus, F. (2011). Cyberpragmatics, Internetmediated communication in context. (A. Fetzer, Ed.) (1st ed.). Amsterdam: John Benjamin Publishing Company. Retrieved from https:// Maslakhah, S. (2017). Eksistensi Bahasa Dalam Iklan Televisi Indonesia. Litera, 16(2), 249-264. https://doi.org/10.21831/1tr. v16i2.15971

https:// nasional.kompas.com/ $\mathrm{read} / 2020 / 04 / 18 / 18201881 /$ menkominfo-sebut-ada-554-isuhoaks-tentang-covid-19. 